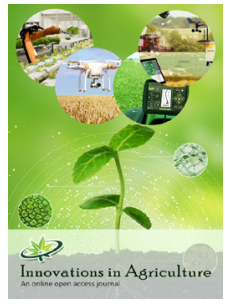

\title{
Effect of different age of seedlings on the growth and yield performance of transplanted Aus rice variety
}

\author{
Md. Khairul Islam, Kawsar Hossen*, Mithila Afroge, Amran Hosen, \\ Kazi A. A. Matin Masum, Muhammad Asif Osman, Md. Istiak Hossain Joy, \\ Farhana Yasmin Chowdhury
}

Department of Agriculture, Noakhali Science and Technology University, Noakhali-3814, Bangladesh

\begin{abstract}
An experiment was conducted in the Agriculture Field Laboratory, Noakhali Science and Technology University (NSTU) to evaluate the effects of age of seedlings on the yield and growth performance of transplanted Aus (T. Aus) rice variety from April 2019 to July 2019. The experiment was carried out assigning four age of seedlings $\left(\mathrm{T}_{1}=22\right.$-day old, $\mathrm{T}_{2}=$ 24-day old, $\mathrm{T}_{3}=27$-day old, $\mathrm{T}_{4}=30$-day old) and two rice varieties $\left(\mathrm{V}_{1}=\mathrm{BRRI}\right.$ dhan83, $\mathrm{V}_{2}=\mathrm{BRRI}$ dhan65). The experiment was laid out in a Randomized Complete Block Design with three replications. In case of variety, the highest plant height $(102.108 \mathrm{~cm})$, the highest grain yield $(2.643 \mathrm{t} / \mathrm{ha})$, and the highest harvest index $(32.317 \%)$ were obtained in BRRI dhan83 where the lowest plant height $(87.804 \mathrm{~cm})$, the lowest grain yield $(2.431 \mathrm{t} / \mathrm{ha})$ and the lowest harvest index $(32.068 \%)$ were obtained in BRRRI dhan65. The age of seedlings had significantly affected total tillers/hill, effective tillers/hill, panicle length in T. Aus rice variety. The highest plant height $(98.16 \mathrm{~cm})$, straw yield $(6.122 \mathrm{t} / \mathrm{ha})$, the maximum number of effective tillers/hill (15.347) were obtained in 24 days old seedlings. The highest grain yield ( $2.634 \mathrm{t} / \mathrm{ha}$ ) was obtained from 27 days old seedlings, and highest harvest index (33.88\%) was obtained from 22 days old seedlings. The lowest grain yield (2.429) was obtained from 24 days old seedlings, and the lowest panicle length $(13.753 \mathrm{~cm})$, harvest index $(30.467 \%)$, and the minimum number of effective tillers/hill (13.753) were obtained from 30 days old seedlings. The lowest straw yield $(5.075 \mathrm{t} / \mathrm{ha})$ and plant height $(93.16 \mathrm{~cm})$ were obtained from 22 days old seedlings. In case of interaction, the highest plant height $(104.667 \mathrm{~cm})$ and the harvest index $(34.86 \%)$ were observed in BRRI dhan 83 at 27 days old seedlings. The highest straw yield $(5.805 \mathrm{t} / \mathrm{ha})$ was observed in BRRI dhan 65 at 30 days old seedlings. The maximum number of effective tillers/hill (18.519) was observed in BRRI dhan83 at 24 days old seedlings. The highest grain yield ( $2.94 \mathrm{t} / \mathrm{ha}$ ) was observed in BRRI dhan 83 at 22 days old seedlings. The lowest plant height $(80.67 \mathrm{~cm})$ was observed in BRRI dhan65 at 27 days old seedlings. The minimum number of total tillers/hill (17.01) was observed in BRRI dhan83 at 22 days old seedlings; lowest panicle length $(20.78 \mathrm{~cm})$, minimum number of grains/panicle (68.07) were observed in BRRI dhan65 at 24 days old seedlings; 1000 grains weight $(22.76 \mathrm{~g})$, the lowest grain yield (2.18 t/ha) were observed in BRRI dhan83 at 24 days old seedlings; the lowest straw yield (4.54 t/ha) was observed in BRRI dhan65 at 22 days seedlings old and lowest harvest index $(29.09 \%)$ were observed in BRRI dhan65 at 30 days old seedlings. Based on the above results, it may be concluded that almost all of the yield and yield contributing characters of T. Aus rice performed best under the interaction between age of seedlings 22 days old seedlings and the variety BRRI dhan 85 .
\end{abstract}

*Corresponding Author:

Kawsar Hossen

E-mail: kwsarbau@gmail.com

KEYWORDS: Transplanted Aus rice variety, age of seedlings, date of transplanting

\section{INTRODUCTION}

Bangladesh is an agrarian country. About $76 \%$ of the people live in rural areas, and $47.5 \%$ of the total manpower is involved in agriculture. In Bangladesh, agriculture contributes 17\% of the gross domestic product (GDP) of the country (BBS, 2014). Bangladesh has a long history of rice cultivation. Rice is grown throughout the country except in the southeastern hilly areas. The agroclimatic conditions of the country are suitable for growing rice year-round. However, the national average rice yield is much lower (2.94 t/ha) than that of other rice-growing countries (BBS, 2012). During the years 201718 , in Bangladesh, rice covered an area of 11620 thousand hectares with a production of 36279 thousand metric tons. Boro rice covers 4862 thousand hectares with a production of 19576 thousand metric tons. Aman rice covers 5683 thousand hectares with a production of 13993 thousand metric tons. Aus rice covers 1075 thousand hectares with a production of 2710

Copyright: $\odot$ The authors. This article is open access and licensed under the terms of the Creative Commons Attribution License (http://creativecommons.org/licenses/by/4.o/) which permits unrestricted, use, distribution and reproduction in any medium, or format for any purpose, even commercially provided the work is properly cited. Attribution - You must give appropriate credit, provide a link to the license, and indicate if changes were made. 
thousand metric tons. Here we see that Boro rice contributes $54 \%$, Aman rice $39 \%$, and Aus rice contribute only $7 \%$ of total rice production. Aus rice cultivation is neglected in our country it occupied only $9 \%$ of total rice-growing area in 2017. Due to rapid population growth and urbanization, cultivated land is gradually decreasing, demanding increased output to keep pace with the population increase. In Bangladesh, the yield of the present high-yielding rice varieties has reached a plateau, and plant types with higher yield potential are now needed to overcome this yield stagnation and meet the demands of the ever-increasing population. Among the different components of agronomy packages for rice cultivation, the date of transplanting is one of the important factors as early or late planting the rice plants may face different types of abiotic stress.

Aus rice has been contributing to food production in addition to other two rice crops (Aman and Boro) until mid-1980s. Aus rice began to lose its importance as farmers slowly started shifting to cultivation of irrigated Boro rice encouraged by its higher yields. The acreage during the Aus season dwindled around 10 lakh ha now, in 30 lakh ha in early 1980s. The word Aus has been derived in the Sanscrit Ashu meaning quick or early. Its life span is very short, only 90-120 days where Boro rice requires 150-200 days. Aus rice is grown under rain-fed conditions where water is not controlled by levees around the land. The topography varies mainly in highland to medium highland and requires less irrigation because of monsoon during its growth period. The Aus crop has to encounter a lot of adverse conditions. The season starts with scorching sun with sporadic drought at the beginning. Some years the field goes so dry having no rain for few months before sowing. By nature, the Aus rice is tolerant to drought at the vegetative stage and high temperature at the reproductive stage.

The reason behind the falling of Aus rice production is unavailability of land as its seed sowing or transplanting period falls during the March and April months when Boro rice remains in the field. Farmers are not getting enough time and land to grow Aus rice. Also, severe insect pest infestation and birds attack cause huge damage to yield in Aus season. Another important reason for low yield of rice is the age of seedlings that are used for cultivation. The yield of transplant Aus rice can be increased with improved cultivation practices like proper age of seedlings. The use of seedlings in the same source having the same sowing date first transplanted at optimum date and thereafter at different dates is termed as staggered planting of rice seedlings having different ages. Transplanting of healthy seedlings of optimum age ensures better rice yield. When seedlings are transplanted at right time, tillering and growth proceed normally. Seedlings age is an important factor due to its tremendous influence on plant height, tiller production, panicle length, grains per panicle and other yield contributing characters some short-duration T. Aus rice varieties (viz. BRRI dhan65, BRRI dhan83) are not only photo insensitive, but also salt-tolerant (BINA, 2007; BRRI, 2019).

Choosing optimum date of transplanting for high-yielding cultivars occupies an important part of high production package (Akhtar et al., 2007). Different authors used different planting dates to check contrasting temperature regimes, precipitation, and growth periods in various T. Aus rice varieties (Labore, 2012; Xu \& Rahman, 2004; Rahman, 2007). They concluded that late transplanting date coincided reproductive phase with temperature stress. But early planting could not be possible all the time due to existing cropping patterns, climate change, and socio-economic conditions. The study was undertaken to observe the performance, the effects of different planting dates, and the interaction effect of different T. Aus rice varieties in respect of yield. With the increasing rate of our population growth, we have to ensure proper utilization of land to increase rice production. In this case of optimum age of seedlings is an important factor.

\section{MATERIALS AND METHODS}

The experiment was carried out in the Agriculture Field Laboratory, Noakhali Science and Technology University, Noakhali during the period from April to July 2019. Particle size constitution of the soil of that site is Sand: Silt: Clay $=40 \%$ : 40\%: $20 \%$. The soil type is loam with organic matter $(0.68 \%)$, with total nitrogen of $0.04 \mathrm{~g} / \mathrm{kg}$, available P of $27.79 \mu \mathrm{g} / \mathrm{g}$, and available $\mathrm{K}$ of $0.18 \mathrm{meq} / \mathrm{l} 00 \mathrm{~g}$ soil with soil is $\mathrm{P}^{\mathrm{H}}$ value 7.5 . The soil index was determined before rising of seedlings. The average annual temperature is $25.6^{\circ} \mathrm{C}$ and the average annual rainfall is about $3,302 \mathrm{~mm}$.

The experiment was laid out in Randomized Complete Block Design (RCBD) with 3 replications. The size of the unit plot was $3 \mathrm{~m} \times 2 \mathrm{~m}$ with an area of $6 \mathrm{~m}^{2}$. Each of the replications represented a block in the experiment. Four treatment combinations were randomly assigned in each replication. Thus, the total number of the plot was $24(3 \times 2 \times 4)$ for this experiment. The density of plant (156 plants/plot) was maintained in between the replications and unit plot respectively.

This experiment was conducted using 2 Aus varieties viz. BRRI dhan83 $\left(\mathrm{V}_{1}\right)$ and BRRI dhan65 $\left(\mathrm{V}_{2}\right)$. There were four treatments including $\mathrm{T}_{1}=22$ days old seedlings ( $12^{\text {th }}$ May $), \mathrm{T}_{2}=24$ days old seedlings ( 14 th May), $\mathrm{T}_{3}=27$ days old seedlings ( $17^{\text {th }}$ May), $\mathrm{T}_{4}=30$ days old seedlings ( $20^{\text {th }}$ May).

Seeds were collected from Bangladesh Rice Research Institute (BRRI), Gazipur, Bangladesh. The experimental land was first opened with a tractor. Later on, the land was prepared by plowing and repeated plowing and subsequently leveled by laddering. Pre-germinated seeds were broadcasted uniformly in a well-prepared nursery bed on 20 April 2019. The basal dose of fertilizer was Triple superphosphate (TSP), Muriate of potash (MoP), and Gypsum at every plot uniformly 7 days before transplanting through broadcasting at a rate of $100 \mathrm{~kg}, 70 \mathrm{~kg}$, $60 \mathrm{~kg} \mathrm{ha}^{-1}$ respectively. Urea was applied at a rate of $150 \mathrm{~kg} \mathrm{ha}^{-1}$ by top dressing in three equal splits at 15,25, and 35 days after transplanting (DAT). Uprooted seedlings were transplanted in the unit plots on $12^{\text {th }}$ May, $14^{\text {th }}$ May, $17^{\text {th }}$ May, and $20^{\text {th }}$ May 2019 respectively maintaining spacing of $25 \mathrm{~cm} \times 15 \mathrm{~cm}$ (row to row and plant to plant) at the rate of 2-3 seedlings per hill. 
Hand weeding was done at 15 and 30 days after transplanting (DAT). Artificial irrigation (5-6 times) were provided to the field as extreme drought condition exists in this season. At the milky stage of rice, plants were found to be attacked by Rice Bug. To control insect Malathion 57 EC and Virtako as per recommended dose were used. Birds attacked severely at maturity stage. It creates serious trouble and causes serious yield loss although scarecrow was used, it reduced intensity but failed to stop bird attack completely.

Five hills (excluding border hills) were selected randomly in each unit plot and uprooted before harvesting for recording data. After sampling, the experimental crop of each plot was harvested when about $80 \%$ of the grains became golden yellow. The harvested crop of each unit area was separately bundled, properly tagged, and then brought to the threshing floor. The harvested crop was threshed by a pedal thrasher. Grains were then sun-dried at $14 \%$ moisture level and cleaned. Straws were also sun-dried properly. Finally, straw and grain yield per plot were recorded and converted to ton per hectare.

Analysis of variance was done with the help of MSTAT-C computer package program (Russell, 1986).

\section{RESULTS AND DISCUSSION}

\section{Effect of Variety on Growth and Yield Attributes of T. Aus Rice}

The two varieties differ significantly in every growth parameters except panicle length, grain yield, straw yield, and harvest index (Table 1). BRRI dhan83 showed a plant height of $102.108 \mathrm{~cm}$ where $87.804 \mathrm{~cm}$ plant height was observed in BRRI dhan65. According to BRRI fact sheet in optimum condition, the average plant height of BRRI dhan83 and BRRI dhan65 is respectively $100-105 \mathrm{~cm}$ and $90-95 \mathrm{~cm}$ (BRKB, 2014; BRKB, 2018). The highest total number of tillers hill-1 ${ }^{-1}$ 21.212) was found in BRRI dhan65 and total number of tillers hill-1 in BRRI dhan83 was 18.956. The highest number of effective tillers hill-1 ${ }^{-1}$ (17.562) was found in BRRI dhan65 where effective tillers hill-1 of BRRI dhan 83 was 11.342. Significant variations in number of effective tillers hill ${ }^{-1}$ among the different varieties were also reported by Islam et al. (2018). The highest panicle length $(22.688 \mathrm{~cm})$, number of grains panicle ${ }^{-1}(104.177)$, sterile grains panicle ${ }^{-1}$ (42.667), and 1000 grains weight $(26.573 \mathrm{gm})$ were obtained from BRRI dhan 83 and the lowest panicle length $(21.308 \mathrm{~cm})$, number of grains panicle ${ }^{-1}(83.497)$, sterile grains panicle ${ }^{-1}$
(33.317) and 1000 grains weight $(23.610 \mathrm{gm})$ were obtained from BRRI dhan65. Significant variation in panicle length, number of grains panicle $\mathrm{e}^{-1}$ and 1000 grains weight were also reported by Mondal et al. (2013) among four Aus rice varieties. Varietal differences might be occurred due to differences in genetic constituents.

Grain yield, straw yield, and harvest index were significantly influenced by variety (Table 1). The grain yield of BRRI dhan 83 was $2.643 \mathrm{t} \mathrm{ha}^{-1}$ and grain yield of BRRI dhan65 was $2.431 \mathrm{t} \mathrm{ha}^{-1}$. The highest grain yield in BRRI dhan83 might be due to the result of highest number of grains panicle $^{-1}$ and 1000 grains weight. The significant difference in grain yield might be due to the genetic characteristics of varieties. Extreme birds attack impedes this experiment to get satisfactory grain yield. Straw yield of BRRI dhan83 was significantly higher $5.490 \mathrm{t} \mathrm{ha}^{-1}$ than BRRI dhan65 $(5.136 \mathrm{t}$ $\left.h^{-1}\right)$. The highest straw yield obtained from BRRI dhan 83 might be due to the huge variation in tillers hill-1 between two varieties. Harvest index of $32.317 \%$ was obtained from BRRI dhan83 where harvest index of BRRI dhan65 was $32.068 \%$. Variety had a great influence on harvest index as reported by Tyeb et al. (2013).

\section{Effect of Different Seedlings Age on Growth and Yield Attributes of T. Aus Rice}

Different seedlings age had significant effect on 1000 grains weight but plant height, total number of tillers hill-1, effective tillers hill-1 ${ }^{-1}$, panicle length, number of grains panicle ${ }^{-1}$, and sterile grains panicle ${ }^{-1}$ remained non-significant in this experiment (Table 2). The highest plant height $(98.16 \mathrm{~cm})$ was found in 24 days age-old of seedlings and the lowest plant height $(92.71 \mathrm{~cm})$ in 27 days old of seedlings. This might be due to the fact that optimum age of seedlings (which in this case was 24 days aged seedlings) helped crop to complete its vegetative phase in favorable climatic conditions. Sarkar et al. recorded more plant height $(130.60 \mathrm{~cm})$ at harvest in case of 25 days old seedlings while minimum of $127.54 \mathrm{~cm}$ was observed when seedlings of 35 days were transplanted. It was investigated that seedlings of 14 days age produced taller plants $(89.50 \mathrm{~cm})$ at harvest compared to older seedlings of 21 days (Sarkar et al., 2011). The total maximum number of tillers/hill (21.046) was found in 24 days age of seedlings and the minimum number (18.13) was found in 22 days age of seedlings. Faghani et al. (2011) found the significant effect of seedlings age on tillering pattern, maximum tillers/ hill (16.3) were recorded by transplanting 25 days old seedlings while 35 days seedlings gave minimum tillers/hill (15.3). It was

Table 1: Effect of variety on growth and yield attributes of T. Aus rice

\begin{tabular}{|c|c|c|c|c|c|c|c|c|c|c|}
\hline Variety & $\begin{array}{c}\text { Plant } \\
\text { height }(\mathrm{cm})\end{array}$ & $\begin{array}{l}\text { Total no. of } \\
\text { tillers hill }\end{array}$ & $\begin{array}{l}\text { Effective } \\
\text { tillers hill-1 }\end{array}$ & $\begin{array}{c}\text { Panicle } \\
\text { length }(\mathrm{cm})\end{array}$ & $\begin{array}{l}\text { Number } \\
\text { of grains } \\
\text { panicle-1 }\end{array}$ & $\begin{array}{c}\text { Sterile grains } \\
\text { panicle }\end{array}$ & $\begin{array}{c}1000 \\
\text { grains } \\
\text { weight }(\mathrm{gm})\end{array}$ & $\begin{array}{l}\text { Grain } \\
\text { yield } \\
\left(\mathrm{t} \mathrm{ha}^{-1}\right)\end{array}$ & $\begin{array}{l}\text { Straw } \\
\text { yield } \\
\left(\mathrm{t} \mathrm{ha}^{-1}\right)\end{array}$ & $\begin{array}{l}\text { Harvest } \\
\text { index (\%) }\end{array}$ \\
\hline BRRI dhan83 $\left(V_{1}\right)$ & 102.108 & 18.956 & 11.342 & 22.688 & 104.177 & 42.667 & 26.573 & 2.643 & 5.490 & 32.317 \\
\hline BRRI dhan65 $\left(V_{2}\right)$ & 87.804 & 21.212 & 17.562 & 21.308 & 83.497 & 33.317 & 23.610 & 2.431 & 5.136 & 32.068 \\
\hline C.V. $(\%)$ & 9.96 & 29.32 & 22.29 & 5.89 & 28.01 & 24.99 & 6.52 & 23.03 & 15.92 & 12.83 \\
\hline Level of Significance & $* *$ & $* *$ & $* *$ & $* *$ & $* *$ & ns & $* *$ & ns & ns & * \\
\hline
\end{tabular}

**=Significant at $1 \%$ level of probability, * = Significant at $5 \%$ level of probability, ns= Non-significant 
Table 2: Effect of different seedlings age on growth and yield attributes of T. Aus rice

\begin{tabular}{lccccccccc}
\hline Treatments & $\begin{array}{c}\text { Plant } \\
\text { height }(\mathrm{cm})\end{array}$ & $\begin{array}{c}\text { Total no. of } \\
\text { tillers hill }\end{array}$ & $\begin{array}{c}\text { Effective } \\
\text { tillers hill-1 }\end{array}$ & $\begin{array}{c}\text { Panicle } \\
\text { length }(\mathrm{cm})\end{array}$ & $\begin{array}{c}\text { Number of } \\
\text { grains panicle }\end{array}$ & $\begin{array}{c}\text { Sterile grains } \\
\text { panicle }^{-1}\end{array}$ & $\begin{array}{c}\text { 1000 grains } \\
\text { weight (gm) }\end{array}$ & $\begin{array}{c}\text { Grain yield Straw yield } \\
\left(\mathrm{t} \mathrm{ha}^{-1}\right)\end{array}$ & $\begin{array}{c}\text { Harvest } \\
\left(\mathrm{t} \mathrm{ha}^{-1}\right)\end{array}$ \\
index $(\%)^{(\%)}$
\end{tabular}

** = Significant at $1 \%$ level of probability, * = Significant at 5\% level of probability, ns= Non-significant

observed that the highest number of effective tillers/hill (15.347) was found when 24 days old seedlings were transplanted. Lowest number of effective tillers/hill (13.756) was produced when 30 days old seedlings are transplanted. Ali et al. reported more effective tillers/hill (24.9) when seedlings of 15 days age were transplanted while 30 days old seedlings gave minimum number of effective tillers (15.6) (Ali et al., 2013). Sarkar et al. did not find a significant effect of seedlings age on effective tillers/hill. They recorded 9.24 and 9.08 effective tillers/hill in case of 25 and 35 days old seedlings which were statistically same. It was observed that younger seedlings of 14 days age produced more productive tillers $/ \mathrm{m}^{2}$ (501) as compared to older seedlings which gave minimum (401) productive tillers $/ \mathrm{m}^{2}$ observed that 4 weeks old seedlings produced more effective tillers/hill (8.26) while minimum number of effective tillers was obtained in 2 weeks old seedling (Sarkar et al., 2011).

It was observed that the longest panicle length (15.374) was found when 24 days old seedlings are transplanted. The shortest panicle length (13.753) was produced when 30 days old seedlings are transplanted. Sarkar et al. found significant effect of seedling age of panicle length, they recorded more panicle length $(27.98 \mathrm{~cm})$ in seedlings of 25 days age while minimum $(27.36 \mathrm{~cm})$ in older seedlings of 35 days (Sarkar et al., 2011). The highest number of grains panicle ${ }^{-1}$ (99.994) was obtained on 30 days old seedlings and the lowest (83.354) was produced on 24 days old seedlings. Ali et al. reported the significant effect of seedling age on number of filled grains panicle ${ }^{-1}$, maximum number of filled grains (188) was obtained by transplanting younger seedlings ( 15 days) while minimum number of filled grains (170) was recorded using older seedlings of 30 days age (Ali et al., 2013). The highest number of sterile spikelets per panicle (38.963) was recorded at 30 days old and the lowest (37.333) was recorded at 27 days old. Rahimpour et al. checked the effect of seedlings age on rice cultivars and found the significant effect of seedlings age on number of spikelets/panicle. Maximum number of spikelets (114.6) was recorded with the seedlings of 27 days age while minimum (106.4) was recorded in case of 30 days old seedlings (Rahimpour et al., 2013). The highest 1000 grains weight $(25.853 \mathrm{~g})$ was recorded on 24 days old and the lowest $(24.617 \mathrm{~g})$ weight of thousand grain on 30 days old. Biswas and Salokhe, and Tari et al. stated that appropriate time of transplanting resulted in higher 1000 grain weight (Biswas \& Salokhe, 2001; Tari et al., 2007). The highest grain yield of
(2.597 t/ha) was recorded on 22 days old seedlings. The lowest ( $2.429 \mathrm{t} / \mathrm{ha}$ ) yield was obtained on 24 days old seedlings. Barr et al. also reported significant effect of seedling age on paddy yield. According to their finding's younger seedlings of 30 days age produced more grain yield ( $6.82 \mathrm{t} / \mathrm{ha}$ ) as compared to older seedlings of 60 days which produced minimum grain yield (6.47t/ha) (Brar et al., 2012). The highest straw yield (5.665 t/ha) was recorded on 30 days old seedlings. The lowest $(5.075 \mathrm{t} / \mathrm{ha})$ was obtained on 22 days old seedlings. The highest (33.882\%) on 22 days old seedlings and the lowest (30.467\%) on 30 days old seedlings. Ginigaddara and Ranamukhaarachchi reported maximum harvest index $(0.51 \%)$ by transplanting 9 days old seedlings (Ginigaddara \& Ranamukhaarachchi, 2011).

\section{Interaction Effect of Variety and Different Seedlings Age on Growth and Yield Attributes of T. Aus Rice}

Interaction between variety had significant effect only on 1000 grains weight (Table 3). Highest weight of thousand grains $(27.41 \mathrm{gm})$ was found in 27 days old seedlings for BRRI dhan83 $\left(\mathrm{T}_{3} \mathrm{~V}_{1}\right)$ and the lowest 1000 grains weight $(22.767 \mathrm{gm})$ was observed in 30 days old seedlings of BRRI dhan65 $\left(\mathrm{T}_{4} \mathrm{~V}_{2}\right)$. The tallest plant $104.667 \mathrm{~cm}$ was observed in BRRI dhan83 at 27 days old seedlings $\left(\mathrm{T}_{3} \mathrm{~V}_{1}\right)$ and the shortest plant 80.672 $\mathrm{cm}$ was observed from BRRI dhan65 at 27 days old seedlings $\left(\mathrm{T}_{3} \mathrm{~V}_{2}\right)$. The highest total number of tillers hill-1 ${ }^{-1}(22.889)$ was observed in BRRI dhan65 at 30 days old seedlings $\left(\mathrm{T}_{4} \mathrm{~V}_{2}\right)$ and lowest total number of tillers hill-1 ${ }^{-17.018)}$ was observed in BRRI dhan 83 at 22 days old seedlings $\left(\mathrm{T}_{1} \mathrm{~V}_{1}\right)$. Effective tillers hill $^{-1}$ was remained non-significant by the interaction between variety and different age of seedlings. The highest number of effective tillers hill-1 ${ }^{-1}$ (18.519) was observed in BRRI dhan65 at 24 days old seedlings $\left(T_{2} V_{2}\right)$ and lowest effective tillers hill ${ }^{-1}$ (10.222) was observed in BRRI dhan83 at 27 days old seedlings $\left(\mathrm{T}_{3} \mathrm{~V}_{1}\right)$. The highest length of panicle $(23.522 \mathrm{~cm})$ was observed in BRRI dhan 83 at 27 days old seedlings $\left(\mathrm{T}_{3} \mathrm{~V}_{1}\right)$ and the lowest length of panicle $(20.780 \mathrm{~cm})$ was observed from BRRI dhan 65 at 24 days old seedlings $\left(\mathrm{T}_{2} \mathrm{~V}_{2}\right)$. The highest number of grains panicle $^{-1}(120.765)$ was observed in BRRI dhan 83 both at 30 days old seedlings $\left(\mathrm{T}_{4} \mathrm{~V}_{1}\right)$ and the lowest grains panicle ${ }^{-1}(68.074)$ was observed from BRRI dhan65 at 24 days old seedlings $\left(\mathrm{T}_{2} \mathrm{~V}_{2}\right)$. The maximum number of sterile grains panicle-1 (47.704) was observed in BRRI dhan83 at 30 days old seedlings $\left(\mathrm{T}_{4} \mathrm{~V}_{1}\right)$ and 
Table 3: Interaction effect of variety and different seedlings age on growth and yield attributes of T. Aus rice

\begin{tabular}{|c|c|c|c|c|c|c|c|c|c|c|}
\hline Interactions & $\begin{array}{c}\text { Plant } \\
\text { height }(\mathrm{cm})\end{array}$ & $\begin{array}{l}\text { Total no. of } \\
\text { tillers hill-1 }\end{array}$ & $\begin{array}{l}\text { Effective } \\
\text { tillers hill-1 }\end{array}$ & $\begin{array}{c}\text { Panicle } \\
\text { length }(\mathrm{cm})\end{array}$ & $\begin{array}{l}\text { Number } \\
\text { of grains } \\
\text { panicle }{ }^{-1}\end{array}$ & $\begin{array}{l}\text { Sterile grains } \\
\text { panicle }^{-1}\end{array}$ & $\begin{array}{l}1000 \text { grains } \\
\text { weight (gm) }\end{array}$ & $\begin{array}{l}\text { Grain yield } \\
\left(\mathrm{t} \mathrm{ha}^{-1}\right)\end{array}$ & $\begin{array}{l}\text { Straw yield } \\
\left(\mathrm{t} \mathrm{ha}^{-1}\right)\end{array}$ & $\begin{array}{l}\text { Harvest } \\
\text { index (\%) }\end{array}$ \\
\hline $\mathrm{T}_{1} \mathrm{~V}_{1}$ & 98.909 & 17.018 & 12.575 & 22.569 & 89.977 & 35.989 & 25.867 & 2.940 & 5.607 & 34.073 \\
\hline $\mathrm{T}_{1}^{1} \mathrm{~V}_{2}^{\mathrm{T}}$ & 87.416 & 19.257 & 16.347 & 21.890 & 100.914 & 39.490 & 23.267 & 2.255 & 4.542 & 33.097 \\
\hline $\mathrm{T}_{2} \mathrm{~V}_{1}^{2}$ & 102.738 & 20.610 & 12.176 & 22.487 & 98.630 & 44.419 & 26.403 & 2.181 & 5.539 & 28.493 \\
\hline $\mathrm{T}_{2}^{2} \mathrm{~V}_{2}^{\mathrm{T}}$ & 93.593 & 21.481 & 18.519 & 20.780 & 68.074 & 31.444 & 25.303 & 2.677 & 4.997 & 34.427 \\
\hline $\mathrm{T}_{3}^{2} \mathrm{~V}_{1}^{2}$ & 104.667 & 19.000 & 10.222 & 23.522 & 107.333 & 42.556 & 27.410 & 2.845 & 5.288 & 34.860 \\
\hline $\mathrm{T}_{3}^{3} \mathrm{~V}_{2}^{1}$ & 80.672 & 21.222 & 18.111 & 23.520 & 85.778 & 32.111 & 23.103 & 2.424 & 5.199 & 31.657 \\
\hline $\mathrm{T}_{4} \mathrm{~V}_{1}^{2}$ & 102.118 & 19.198 & 10.395 & 22.175 & 120.765 & 47.704 & 26.467 & 2.604 & 5.524 & 31.840 \\
\hline$T_{4}^{4} V_{2}^{1}$ & 89.444 & 22.889 & 17.111 & 21.522 & 79.222 & 30.222 & 22.767 & 2.368 & 5.805 & 29.093 \\
\hline$C^{4} . V^{2} .(\%)$ & 9.96 & 29.32 & 22.29 & 5.89 & 28.01 & 24.99 & 6.52 & 23.01 & 15.92 & 12.83 \\
\hline Level of significance & ns & ns & ns & ns & ns & ns & * & ns & ns & ns \\
\hline
\end{tabular}

* = Significant at $5 \%$ level of probability, $\mathrm{ns}=$ Non-significant

the lowest grains panicle ${ }^{-1}$ (30.222) was observed from BRRI dhan65 at 30 days old seedlings $\left(\mathrm{T}_{4} \mathrm{~V}_{2}\right)$.

Maximum grain yield $\left(2.940 \mathrm{tha}^{-1}\right)$ was observed in BRRI dhan83 at 22 days old seedlings $\left(\mathrm{T}_{1} \mathrm{~V}_{1}\right)$ application and the lowest grain yield $\left(2.181 \mathrm{t} \mathrm{ha}^{-1}\right)$ was observed at 24 days old seedlings in BRRI dhan83 $\left(\mathrm{T}_{2} \mathrm{~V}_{1}\right)$. The maximum straw yield $\left(5.805 \mathrm{tha}^{-1}\right)$ was observed in BRRI dhan65 at 30 days old seedlings $\left(\mathrm{T}_{4} \mathrm{~V}_{2}\right)$ and the minimum straw yield $\left(5.199 \mathrm{tha}^{-1}\right)$ was observed at 27 days old seedlings in BRRI dhan65 $\left(\mathrm{T}_{3} \mathrm{~V}_{2}\right)$. The maximum harvest index $(34.86 \%$ ) was observed in BRRI dhan83 at 27 days old seedlings $\left(\mathrm{T}_{3} \mathrm{~V}_{1}\right)$ application and the minimum harvest index (28.493\%) was observed at 24 days old seedlings in BRRI dhan83 $\left(\mathrm{T}_{2} \mathrm{~V}_{1}\right)$.

\section{CONCLUSION}

Age of seedlings are always important for plant growth and to produce more yield of different rice varieties. Farmers hardly follow the appropriate methods of selecting the age of seedlings for each different rice varieties that's why Aus rice production in Bangladesh still falling behind. Bangladesh can easily uplift her production by emphasizing more research work on Aus rice by undertaking a focus on the performance, the effects of different planting dates, and the interaction effect of different Aus rice varieties in respect of yield. In this study among the tested different T. Aus rice varieties, based on the results, it may be concluded that almost all of the yield and yield contributing characters of $T$. Aus rice performed best under the interaction between 22 days old seedlings and the BRRI dhan 85 rice variety. This experiment was also interrupted by extreme birds attack at the maturity stage and so impedes to get the desired yield, otherwise, there was a possibility to obtain outstanding yield in Aus rice. So, it is one of the captivating topics for the enthusiast researchers of Bangladesh to find out the most efficient seedling age in Aus rice which will ensure an economic rice production. In Bangladesh few studies have attempted to this topic, however, to attain a final decision more research work on Aus rice with the same treatment should be done in different Agro-ecological Zones (AEZs) of Bangladesh.

\section{CONFLICT OF INTEREST}

The authors declare that there is no conflict of interests regarding the publication of this paper.

\section{REFERENCES}

Akhtar, M. Z., Khan, A., Sarwar, M., \& Javaid, A. (2007). Influence of soil and forage minerals on buffalo (Bubalus bubalis) parturient haemoglobinuria. Asian-Australasian Journal of Animal Sciences, 20(3), 393-398. https://doi.org/10.5713/ajas.2007.393

Ali, M. S., Hasan, M. A., Sikder, S., Islam, M. R., \& Hafiz, M. H. (2013). Effect of seedling age and water management on the performance of boro rice (Oryza sativa L.) variety BRRI dhan28. The Agriculturists, 11(2), 28-37. https://doi.org/10.3329/agric.v11i2.17484

BINA (Bangladesh Institute of Nuclear Agriculture). (2007). A booklet on "BINA profile". Bangladesh Institute of Nuclear Agriculture, Mymensingh. pp. 25.

Biswas, P. K., \& Salokhe, V. M. (2001). Effects of planting date, intensity of tiller separation and plant density on the yield of transplanted rice. The journal of Agricultural science, 137(3), 279-287. https://doi. org/10.1017/S0021859601001307

Brar, S. K., Mahal, S. S., Brar, A. S., Vashist, K. K., Sharma, N., \& Buttar, G. S. (2012). Transplanting time and seedling age affect water productivity, rice yield and quality in north-west India. Agricultural Water Management, 115, 217-222. https://doi.org/10.1016/j.agwat.2012.09.001

BBS (Bangladesh Bureau of Statistics). (2012). Statistical Year Book of Bangladesh. Statistics and Informatics Division (SID), Ministry of Planning, Government of the People's Republic of Bangladesh.

BBS (Bangladesh Bureau of Statistics). (2014). Yearbook of Agricultural Statistics. Statistics and Informatics Division (SID), Ministry of Planning, Government of the People's Republic of Bangladesh.

BRKB (Bangladesh Rice Knowledge Bank). (2014). BRRI Dhan65. Available from: http://knowledgebank-brri.org/wp-content/uploads/2014/02/ BRRIDhan-65.pdf [Last accessed on 2020 April 16].

BRKB (Bangladesh Rice Knowledge Bank). (2018). BRRI Dhan83. Available from: http://knowledgebank-brri.org/wp-content/uploads/2018/01/ BRRI-dhan83.pdf [Last accessed on 2020 April 16].

BRRI (Bangladesh Rice Research Institute). (2019). Aus Rice Varieties. Bangladesh Rice Knowledge Bank. Available from: http:// knowledgebank-brri.org/brri-rice-varieties/aus-rice-varieties/ [Last accessed on 2020 April 16].

Faghani, R., Mobasser, H. R., Dehpor, A. A., \& Kochaksarai, S. T. (2011). The effect of planting date and seedling age on yield and yield components of rice (Oryza sativa L.) varieties in North of Iran. African Journal of Agricultural Research, 6(11), 2571-2575. https:// doi.org/10.5897/AJAR10.1150

Ginigaddara, G. A. S., \& Ranamukhaarachchi, S. L. (2011). Study of age of seedlings at transplanting on growth dynamics and yield of rice under alternating flooding and suspension of irrigation of water management. Recent Research in Science and Technology, 3(3), 76-88.

Islam, A. K. M. M., Hia, M. A. U. H., Sarkar, S. K., \& Anwar, M. P. (2018). Herbicide based weed management in aromatic rice of Bangladesh. Journal of the Bangladesh Agricultural University, 16(1), 31-40.

Labore, N. (2012). Transition to self-management: the lived experience of 21-25-year-old with sickle cell disease. [Dissertation]. Massachusetts: University of Massachusetts Lowell.

Mondal, B. R., Sarkar, M. A. R., Paul, S. K., \& Zaman, F. (2013). Effect of variety and weeding regime on the yield components and yield of 
Islam, et al.

Aus rice. Journal of the Bangladesh Agricultural University, 11(1), 17-21. https://doi.org/10.22004/ag.econ.209738

Rahman, M. A., inventor; Nokia of America Corp, assignee. (2007 Jan 30). Method and system for directing a data message in a wireless communications network including multiple wireless systems. U.S. Patent No. 7,171,199. Washington, DC: U.S. Patent and Trademark Office.

Rahimpour, L., Daliri, M. S., \& Mousavi, A. A. (2013). Effect of seedling age on yield and yield component of rice cultivars (Oryza sativa L.). Annals of Biological Research, 4(2), 72-76.

Russell, D. F. (1986). MSTAT-C package programme (pp. 59-60). Crop and Soil Sciences Department, Michigian State University, USA.

Sarkar, M. A. R., Paul, S. K., \& Hossain, M. A. (2011). Effect of row arrangement, age of tiller seedling and number of tiller seedlings per hill on performance of transplant aman rice. Journal of Agricultural Sciences, 6(2), 59-68.

Tari, D. B., Pirdashti, H., Nasiri, M., Gazanchian, \& A., Hoseini, S. S. (2007). Determination of morphological characteristics affected by different agronomical treatments in rice (IR6874-3-2 Promising Line). Asian Journal of Plant Sciences, 6(1), 61-65. https://doi.org/10.3923/ ajps. 2007.61 .65

Tyeb, A., Paul, S. K., \& Samad, M. A. (2013). Performance of variety and spacing on the yield and yield contributing characters of transplanted aman rice. Journal of Agroforestry and Environment, 40(4), 595-597.

Xu, H., \& Rahman, S. (2004). A generalized dimension-reduction method for multidimensional integration in stochastic mechanics. International Journal for Numerical Methods in Engineering, 61(12), 1992-2019. https://doi.org/10.1002/nme.1135 